\title{
RESEARCH ON IMPACT OF EMPLOYER BRAND DIMENSIONS ON COMPETITIVENESS IN HOTEL INDUSTRY
}

\author{
Jasmina Ognjanovic ${ }^{*}$ \\ Faculty of Hotel Management and Tourism in Vrnjačka Banja, \\ University of Kragujevac, Vrnjačka Banja, Republic of Serbia
}

\begin{abstract}
Human resources are one of the key resources for gaining and maintaining the competitive advantage of hotels, so increasing the value of human capital becomes a priority for hotel management. One way to increase the value of human capital is to build an employer brand in the hotel industry. The paper aims to examine the relationship between employer brand and competitiveness in the hotel industry. The obtained research results indicate the importance of the following five dimensions of the employer brand: organizational culture, work-life balance, the attractiveness of the hotel, corporate social responsibility, opportunities for training, development and advancement of employees. Results of correlation analysis indicate a positive, significant correlation between employer brand dimensions, while the regression analysis results support the impact of the hotel's employer brand on competitiveness. Corporate social responsibility has a significant impact on competitiveness as one of the dimensions of an employer brand.
\end{abstract}

Keywords: employer brand, human resource management, employee, human capital, competitiveness, hotels, Serbia

\section{ISTRAŽIVANJE UTICAJA BRENDA POSLODAVCA NA KONKURENTNOST U HOTELSKOJ INDUSTRIJI}

Sažetak: Ljudski resursi predstavljaju jedan od ključnih resursa za sticanje i održavanje konkurentske prednosti hotela, pa uvećavanje vrednosti ljudskog kapitala postaje prioritet za menadžment hotela. Jedan od načina da se vrednost ljudskog kapitala uveća jeste izgradnja brenda hotela kao potencijalnog poslodavca. Cilj rada je ispitivanje postojanja povezanosti između brenda poslodavca i konkurentnosti u Srbiji. Dobijeni istraživački rezultati ukazuju na značaj sledećih pet dimenzija brenda poslodavca:

\footnotetext{
*jasmina.lukic.@kg.ac.rs
} 
organizacione kulture, balansa između života i posla, atraktivnosti hotela, korporativne društvene odgovornosti $i$ mogućnosti obuke, razvoja $i$ usavršavanja zaposlenih. Sprovođenjem korelacione analize utvrđeno je prisustvo pozitivne, značajne veze između dimenzija brenda poslodavca, dok rezultati regresione analize podržavaju uticaj brenda poslodavca na konkurentnost. Značajan uticaj na konkurentnost ima korporativna društvena odgovornost, kao jedna od dimenzija brenda poslodavca.

Ključne reči: brend poslodavca, upravljanje ljudskim resursima, zaposleni, ljudski kapital, konkurentnost, hotel, Srbija

JEL classification: J21, J24, M54

\section{INTRODUCTION}

The increasingly pronounced trend of lack of human capital in the global labor market has intensified companies' struggle for employees with professional and managerial skills (Arasanmi \& Krishna, 2019). Therefore, attracting and retaining qualified employees has become a global issue that a well-designed strategic approach can address (Arasanmi \& Krishna, 2019). In such business conditions, most companies have begun to understand the importance of a good employer branding strategy to become competitive and attract a better workforce from the labor market (Tanwar \& Prasad, 2016). Practitioners and academic researchers point out that developing an effective employer branding strategy can provide a strategic advantage to a company by developing engaged employees who are loyal and committed to the company and work to achieve its super-ordinate goals (Chawla, 2020).

The preparation of the human resources management strategy starts from the essential values that emphasize the importance of employees as a source of competitive advantage (Batarlien, Čižiūniene, Vaičiūte, Šapalaite \& Jarašūniene, 2017; Sharma \& Prasad, 2018). According to the resource-based view of strategic management, human capital meets the criteria of value creation and competitive advantage: rare, valuable, non-substitutable and difficult to imitate resources (Backhaus \& Tikoo, 2004; Kucherov \& Zavyalova, 2012). Companies in the services sector must continuously find ways to manage employees to ensure that their behavior contributes to high-quality services (Santiago, 2019). On the other hand, intense competition and an increase in the number of companies from all sectors have encouraged a new employment era. Therefore, the imperative of all companies was to understand the expectations of potential and current employees and create an employer branding strategy to attract and retain talents (Sharma \& Prasad, 2018). The accurate understanding 
and practical application of the principles of the employer brand concept, based on creation, maintenance and positioning of a unique image of the company as an employer in the labor market, could allow a company to operate successfully under the conditions of the so-called "War for Talents" (Kucherov \& Zavyalova, 2012). Research shows that integrating employer brand strategy with sustainable human resource practices can lead to lasting competitive advantage (Rai, 2020) and companies' ability to internalize company values and retain employees (CIPD 2007; Alshathry, Clarke \& Goodman, 2017).

The literature highlights the presence of research gaps in employer brand analysis. First, most employer brand research considers only one target group, potential employees, which has oriented the research conducted to the employer brand analysis on attracting talent to companies (Tanwar \& Prasad, 2016; Alshathry, Clarke \& Goodman 2017). The employer brand concept aims at two target groups: potential employees and current employees (Alshathry et al., 2017), which means that research also needs to cover the relationship between current employees and employer brand. Second, developing the scale to measure employer attractiveness (EmpAt, Instrumental-Symbolic Framework) may not be the best solution for examining employer brand development among current employees (Tanwar, \& Prasad, 2016; Sharma, \& Prasad, 2018). This represents a gap in the literature because the employer brand can generate positive results only if the employer is considered attractive by current employees (Maxwell \& Knox, 2009; Tanwar \& Prasad, 2016). Third, there has been a significant amount of research on the importance of the employer brand in the IT sector. Research on this topic in other industries is not much represented in the existing literature. This could be characterized as another research gap, as the importance of the employer brand concept is growing, so it would be useful to examine the development of these assets by industries. Fourth, despite the rich research contribution in the field of employer branding, the interdisciplinary nature of this concept has not yet been explored (Deepa \& Baral, 2019). Alshathry et al. (2017) suggest that employer brand research must be integrated into the frameworks of marketing literature that recognizes the relational nature of employment.

The paper aims to examine the relationship between employer brand and competitiveness in the hotel industry. The employer brand dimensions that are particularly important for hotel employees are also identified. The research results indicate the most important dimensions that affect the quality of relations between employees and employers and examine the impact of these relations on competitiveness. Identification of the employer brand dimensions that are most important to current employees will make a significant contribution within human resource management when retaining talents and building the hotel's competitive advantage. 
The results of the study should provide answers to the following research questions:

- What employer brand dimensions have been developed in the observed hotels?

- What employer brand dimensions do the hotel employees value the most?

- Can the developed employer brand in the hotel industry affect the gaining and maintenance of the competitive advantage in current business conditions?

- What are the employer brand dimensions in the hotel industry by whose strengthening and investment the employer can gain and maintain the competitive advantage?

The paper, in addition to the introduction and conclusion, contains three more parts. The second part highlights the fundamental conceptual determinants of employer brand, citing previous research results. This part of the paper points to the importance of building a competitive position for hotels, listing the factors that affect it and the relationship between the employer brand dimension and competitiveness. The third part of the paper describes the research instrument and statistical methods applied, with a detailed description of the sample, research model variables and the definition of research hypotheses. The fourth part presents the research results with a discussion of the acceptance of the research hypotheses.

\section{LITERATURE REVIEW}

\subsection{EMPLOYER BRAND}

To meet the challenges of the modern business market, an increasing number of companies are developing an employer branding strategy to strengthen their human capital. Successful implementation of this strategy can become an excellent weapon in the "war for talents" (Kucherov \& Zavyalova, 2012). Employer branding is an effective strategy by which a company attracts talent and, at the same time, differentiates itself from the competition (Deepa \& Baral, 2019). Precise understanding and practical application of employer brand principles are based on creating, maintaining, and positioning a company's unique image as an employer on the labour market, attractive to both potential and current employees (Kucherov \& Zavyalova, 2012). For Chawla (2020), an employer branding strategy involves developing a work environment in which 
employees are allowed to use their entrepreneurial skills and creativity to accomplish business tasks.

Building employer brand equity on the labor market helps create the company's image as an "employer of choice" (Alshathry et al., 2017). Ambler and Barrow (1996, p. 187), among the first, define employer brand as "the package of functional, economic and psychological benefits provided by employment and identified with the employing company". Kucherov and Zavyalova (2012) view the employer brand as a progressive HRD approach based on general branding theory, using some branding principles and tools (target audience identification, segmentation, promotion) and contributing to a more efficient people management process. From an HR perspective, employer branding involves identifying the unique employment experience an organization offers (Maurya \& Agarwal, 2018). According to Alshathry et al. (2017), employer brand equity is based on employee experience resulting from the interaction between the employer and the employees who recognize the internal and external perspectives at the same time. Based on the above, it can be concluded that employer brand is an intangible asset created as a result of successful implementation of employer branding strategy that promotes the company as an excellent employer, provides realistic expectations to labour market candidates and fulfils promises to employees. Both potential and current employees are the focus of employer branding strategy. The paper views employer brand from the perspective of current employees in hotels.

The essence of building an employer brand is to provide a higher degree of employee satisfaction and commitment, which depends on meeting the given expectations. Deepa and Baral (2019) talk about the importance of fulfilling employer promises given to employees in terms of employee commitment and support. They believe that non-fulfilment of promises leads to violation of psychological contracts, which can cause employee turnover and stronger intention to leave the company. Arasanmi and Krishna (2019) also emphasize the importance of fulfilling promises with the help of an employer branding strategy because if promises are kept, employees respond with trust, support and affection, which helps grow organizational performance. A unique employment experience obliges employees to expand their associations to current employers (Kashyap \& Verma, 2018).

The ultimate goal of employer branding is to arouse the interest of potential employees to join the organization, while the goal of current employees is to ensure that they continue to experience the value associated with belonging to the company (Alshathry et al., 2017). By building employer brand assets, companies gain several advantages, including a stronger position on a highly competitive labour market, better results in terms of the quality of registered 
and accepted candidates, and lower employee turnover rates (Alshathry et al. 2017), different economic benefits due to lower employee turnover rates and high investment in employee training and development activities (Kucherov \& Zavyalova, 2012), focus on priorities while increasing work productivity, employee retention and commitment, planning and implementing unique company policies and practices, thus creating a strong and positive employer brand image (Kashyap \& Verma, 2018).

The results of previous research generally support the development of employer brand, providing multiple benefits for companies, primarily by strengthening human capital. Kucherov and Zavyalova (2012) conclude, based on the research results, on significant differences in economic indicators, HRD practices and talent management in companies with a built-in employer brand and companies that do not have this type of asset developed. Kashive, Khanna and Bharthi (2020) conclude that social value is important for the employer brand value assumptions and interest value and work-life value. Maurya and Agarwal (2018) found that organizational talent management is strongly and positively related to the perception of employer branding. The same authors state predictors that are most effective in predicting employer branding. Such an employer rewards and remunerates fairly, manages work-life balance, and attracts and recruits talent. Kashyap and Verma (2018) prove that the observed employer brand dimensions are negatively correlated with the intention of employees to leave the company. In particular, two dimensions, social and developmental value, are important predictors of employees' intention to leave the company. Arasanmi and Krishna (2019) come to similar results, concluding that perceived organizational support is an employer branding technique that affects employee retention. Chawla's (2020) research shows that employer branding has a positive attitude toward person-organization ( $\mathrm{P}-\mathrm{O})$ fit and employee engagement. The same author proves that person-organization (P-O) fit has a partial mediating effect on the relationship between employer branding and employee engagement. Davies, Mete and Whelan (2018) conclude that satisfaction partially mediates the influence of employer brand image on employee engagement. Tanwar and Prasad (2016) point out that employer brand acts as a significant predictor of job satisfaction. Ognjanović and Slavković (2019) also prove the influence of the employer brand on employee satisfaction in hotels. Development and social value mostly influence the satisfaction of hotel employees.

\subsection{COMPETITIVENESS IN HOTEL INDUSTRY}

The competitive position of a hotel depends on how the hotel develops and how it uses resources (Vij, 2016). Respecting the concept of intellectual capital, 
according to Chahal and Bakshi (2015), competitive advantage is the result of rare, valuable and unique human resources, customer relationships and business systems. On a dynamic global market, human capital is becoming the central strategic resource that affects the competitiveness of companies (Slavković \& Ognjanović 2017). The company's competitiveness comes with the help of unique competencies of an individual or human resources, creating greater value (Chahal \& Bakshi 2015). Competitive advantage can also be viewed as a kind of diversity (differentiation) that a company can create in relation to its competitors (Vij, 2016). According to Kim (2000), the competitiveness of the tourism sector is defined as the condition capacity of the tourism market environment, tourism resources, human resources and tourism infrastructure of the country, in order to create added value and increase national wealth (Nunes, Estevão \& Filipe, 2018).

In recent years, company competitiveness has become one of the common concepts for describing methods of sustainable tourism development, taking into account a set of tourism reference points related to the most important industry dimensions, such as business environment, infrastructure, laws and regulations, available resources (Nunes, Estevão \& Filipe, 2018). The rapid growth of international hotel chains has intensified competition in the hotel market, which meant formulating marketing strategies, strengthening business and modernizing service quality (Wang, Huang \& Shang 2006; Nunes et al., 2018). Xiaa, Vuc, Lawd \& Li (2020) believe that understanding the competitiveness of hotel brands is important for managers to shape their brands and initiate effective marketing strategies and business development. However, assessing the competitiveness of hotel brands is challenging due to the complex nature of information on the hotel sector's competitiveness.

Demonstrating the hotel's competitiveness with monetary indicators is not easy since these indicators assess only one dimension of performance. The inclusion of qualitative information can give good results in order to properly assess the results of the competitive activities undertaken (Anderson, 1990; GómezMiranda, Pérez-López, Argente-Linares \& Rodríguez-Ariza, 2015). The competitiveness in the studies conducted so far was mainly expressed qualitatively, using questionnaires where the respondents used the Likert scale to give their subjective assessments of the defined competitiveness findings (Phillips, 1999; Wong \& Kwan, 2001; Ahmad \& Schroeder, 2011; Sigalas, Economou \& Georgopoulos, 2013; Aigner \& Lloret, 2013; Chahal \& Bakshi, 2015; Gómez-Miranda et al., 2015; Baumann, Hamin, Tung \& Hoadley, 2016; Pereira-Moliner, Pertusa-Ortega, Tarí, López-Gamero \& Molina-Azorín, 2016; Sanchez-Gutierrez, Mejia-Trejo, Vargas-Barraza \& Vazquez-Avila, 2016). Phillips (1999) analyzes the competitiveness by asking the respondents to provide the most appropriate description that best represents their hotel 
compared to the competitors in the category of the following inputs: building, capital, staff, IT, on a scale of 1 to 7. Wong and Kwan (2001) analyze the development of hotels' competitive strategies on the Likert scale from 1 to 5 . They observe 9 different areas in which companies can gain a competitive advantage: cost competitiveness, mobilizing people and partner, building service delivery systems, differentiating market offering, delivering service anineross countries, defining service standards and performance, reliance on local vs. expatriate staff, leveraging information technology deliver value, meeting customers' expectations. Chahal \& Bakshi (2015) observe competitive advantage through a qualitative assessment of 38 items grouped into the following dimensions: market share, service delivery, service differentiation, customer understanding. Pereira-Moliner et al. (2016) observe competitive advantage through the differentiation of competitive advantage and costcompetitive advantage. Seven items were considered to measure the competitive advantage variable. The hoteliers had to indicate, on a scale from 1 (they did not use such a strategy at all) to 7 (the strategy is very important for their establishment), their opinion concerning the cost and differentiation competitive advantages pursued by their organization. Batarlien et al. (2017) analyze the HR Sustainable Competitive Advantage Model according to which the following characteristics of human resources are important for the development of competitive advantage: economic value, exclusivity, uniqueness, irreplaceability. Cetindamar and Kilitcioglu (2013) find a theoretical basis for measuring the company's competitiveness in two national competitiveness models: World Competitive Yearbook and Global Competitiveness Index, while the assessment structure is based on the European Foundation for Quality Management Excellence Award. The authors have developed a competitiveness measurement model that has competition parameters applicable to all companies. The model covers a wide variety of parameters that form the base of competition at the firm level. The firm competitiveness is based on three key pillars: competitive outcome/performance (output), firm resources (input), and the managerial processes and capabilities where these firm resources are flourished and utilized. Sigalas et al. (2013) have attempted to develop a reliable and valid measure of competitive advantage by identifying a conceptually robust stipulate definition, composing a comprehensive operational definition and constructing a qualified variable. The variable of firm competitiveness contains four items properly crafted from the observable attributes of competitive advantage's operational definition. The variable of competitive advantage had been created by comparing each firm competitiveness with the average competitiveness of its industry. 
Research results indicate the factors, which, when made stronger and better, can strengthen hotel competitiveness. The competitiveness of the tourism sector includes many factors such as the natural environment (geographical location, landscapes and climate), the man-made environment (tourist transport, leisure and entertainment infrastructure, services, shops and hotel network) (Navickas \& Malakauskaite, 2009; Nunes et al. 2018). The most important factors influencing hotel competitiveness are: government policies, factor conditions, related and supporting industries and cooperation and innovation (Nunes et al., 2018); interaction abilities, learning organization, human resources and information technology (Ioncica, Tala, Brindusoiu \& Ioncica, 2008) technology and IT (Holjevac, 2011); costs, human resources, innovation and services (Tuclea \& Padurean, 2008). Campos-Soria et al. (2005) identify the quality of services as a factor in improving the perceived value, affecting hotel competitiveness. Slavković and Ognjanović (2017) prove the influence of human capital components on the observed hotel competitiveness. The human capital components that most affect hotel competitiveness are employee satisfaction and the entrepreneurial spirit of employees. Dragicevic, Cizmar and Seric (1999) find that market performance analysis and operative effectiveness show the Croatian hotel sector inferior to the respective hotel industries of the analysed countries, judging by all the key indicators. Rodríguez-Victoria, Puig and González-Loureiro (2017) believe that clustering has a direct and positive impact on hotel competitiveness. Also, the positive impact of innovation on hotel competitiveness is noted. The same authors also state that interaction with affiliated companies and the application of innovation management increase economic competitiveness. Vij (2016), guided by Porter's competitiveness strategies, concludes that cost competitiveness is one of the most significant factors affecting the competitiveness and profitability of the hotel sector. Hotels that are more cost-effective than their competitors are likely to survive and profit, unlike those hotels that are not.

\subsection{EMPLOYER BRAND DIMENSIONS AND COMPETITIVENESS}

Competitive advantage is based on the belief that human resources outperform all other resources (Alpander \& Lee, 1995). This implies the development of the employer brand and employer brand dimensions that bring certain benefits to employees and affect the workforce performance and the achievement of company goals. Previous studies link the employer brand dimension and competitive advantage.

Organizational culture represents the values and beliefs that the company's employees create, implement and respect (Ognjanović, 2020). Alpander and Lee (1995) believe that it is necessary to build a climate organization that nurtures creativity, harmony and teamwork, where continuous improvement has become 
a way of life. Organizational culture assumes the existence of a common pattern in how problems related to basic aspects such as the business environment, human capital and social relationships are addressed and solved (GómezMiranda, Pérez-López, Argente-Linares \& Rodríguez-Ariza, 2015, p.365). The relationship between organizational culture and company competitiveness was analyzed in studies (Alpander \& Lee, 1995; Gómez-Miranda et al. 2015; Anning-Dorson, 2021). Alpander and Lee (1995) conclude that culture is one factor that creates an environment where proactive behavior towards change is the norm and the establishment of competitive advantage. Through the organizational culture, companies can build a market-flexible organization to create a competitive advantage (Anning-Dorson, 2021).

Work/life balance refers to keeping the balance between an employee's personal and professional life (Ognjanović, 2020). The companies that have developed this employer brand dimension are becoming more and more attractive on the labor market (Sharma \& Prasad, 2018). However, Kaya and Karatepe (2020) consider work/life balance to be the most important problem of the hotel industry. Different sustainable high-performance work systems, including WLB, are not consistently present in the hotel industry (Kaya \& Karatepe, 2020). Le, Newman, Menzies, Zheng and Fermelis (2020) consider that the resource-based view suggests how employees respond to family-friendly work policies and initiatives by demonstrating the strategic importance of work-life balance initiatives to the competitive advantage of organizations.

As an employer brand dimension, the attractiveness of the company has always been seen as a key means of achieving competitive advantage (Tanwar \& Prasad, 2016). Attractiveness and reputation are seen as an integral part of the employer branding process that can help a company stay in the market in the long run (Tanwar \& Prasad, 2016). Drezner, Drezner and Zerom (2018) concluded that when the company's attractiveness is random, the company loses some competitive advantage. Authors Jain and Bhatt (2015) considered that company attractiveness and organizational culture are key employer brand dimensions that attract a candidate.

Corporate social responsibility plays a key role in the sustainability, competitiveness and innovation of a company and the economy (VelazquezCazares, Leon-Castro, Blanco-Mesa \& Alvarado-Altamirano, 2021). Hoppe (2018) states that corporate social responsibility activities can be crucial for assessing the employer brand. The main reasons why companies choose to invest in corporate social responsibility are the various benefits that these practices bring, including improving competitiveness. (Boulouta \& Pitelis, 2014; Velazquez-Cazares et al., 2021). The impact of corporate social 
responsibility on the competitiveness of companies has been supported by studies (Madue, Jorge, Conesa \& Martínez-Martínez, 2016; Guo \& Lu, 2021; Hadj, 2020). The competitiveness of companies will increase with their corporate social responsibility engagement but will decline when corporate social responsibility costs begin to gain priority (Guo \& Lu, 2021). Madue et al. (2016) concluded that the development of CSR practices contributes to increasing the competitive performance both directly and indirectly through the ability of these organizations to manage their stakeholders.

Training and development represent "the extent to which an individual is attracted to an employer who provides recognition, generates a feeling of selfworth, and provides a career-enhancing experience and a springboard to future employment" (Zhu, Wang, Yu, Hu, Wen \& Liu, 2014, p. 935). Employee training is related to employees' work motivation and thus to the competitiveness positions (Cheung \& Chan, 2012). Cheung and Chan (2012) concluded that investing in employee's training and development can be an effective method for improving competitiveness. Husain, Dayan and Benedetto (2016) conclude that organizational networking leads to competitiveness through organizational learning and innovation process; however, it leads to competitiveness through employee innovativeness.

\section{RESEARCH METHODOLOGY}

\subsection{SAMPLE DESCRIPTION AND RESEARCH INSTRUMENT}

The collection of data on the hotel's employer brand and competitiveness was made using the survey method. Information on the number, type and category of hotels was taken from the website of the Ministry of Trade, Tourism and Telecommunications of the Republic of Serbia. The research sample consists of 90 hotels with the activity code 5510 - Hotels and similar accommodation.

The survey was conducted in December 2018. In order to be the subject of the survey, respondents had to meet certain criteria: (1) only hotel managers were surveyed, (2) III, IV and V star hotels were observed, (3) observed the following types of hotels: garni hotels, hotels and apart-hotels. Keeping in mind the stated criteria, we sent the questionnaire to 273 hotels and 50 questionnaires were returned, while 40 surveys were completed by telephone interview. The response rate is $33 \%$. Table 1 shows the characteristics of the observed sample by category, organizational form, number of employees and the region in which hotels operate.

The sample is dominated by three-star hotels $(60 \%)$, while five-star hotels are the least represented (4\%). The largest number of surveyed managers works in self-organized hotels (87\%) with 10 to 49 employees (57\%) and located in SCHOOL OF BUSINESS, 2/2020, 35-61 
46 | RESEARCH ON IMPACT OF EMPLOYER BRAND DIMENSIONS ON COMPETITIVENESS IN HOTEL INDUSTRY

Belgrade (31\%). The least represented in the sample are hotels with over 250 employees (1\%) and hotels that are part of an international hotel chain (4\%).

Table 1

Description of the sample in terms of category, organizational form, number of employees and the region

\begin{tabular}{lcc}
\hline Category & Number of hotels & $\mathbf{\%}$ \\
\hline$* * * *$ & 54 & 60 \\
$* * * *$ & 32 & 36 \\
$* * * * *$ & 4 & 4 \\
$\sum$ & $\mathbf{9 0}$ & $\mathbf{1 0 0}$ \\
\hline The organizational form of the hotel & Number of hotels & $\mathbf{\%}$ \\
\hline Independent hotel & 78 & 87 \\
Part of the national hotel chain & 8 & 9 \\
Part of an international hotel chain & 4 & 4 \\
$\sum$ & $\mathbf{9 0}$ & $\mathbf{1 0 0}$ \\
\hline Number of employees & Number of hotels & $\mathbf{9}$ \\
\hline Until 9 & 22 & 24 \\
From 10 to 49 & 51 & 57 \\
From 50 to 249 & 16 & 18 \\
250 and more & 1 & 1 \\
$\sum$ & $\mathbf{9 0}$ & $\mathbf{1 0 0}$ \\
\hline Region in which the hotel operates & Number of hotels & $\mathbf{\%}$ \\
\hline Vojvodina & 20 & 22 \\
Belgrade & 28 & 31 \\
Sumadija and Western Serbia & 25 & 28 \\
Southern and Eastern Serbia & 17 & 19 \\
\hline$\sum$ & $\mathbf{9 0}$ & $\mathbf{1 0 0}$ \\
\hline
\end{tabular}

Note. Authors' calculations.

The questionnaire is used as a research instrument in the paper and consists of three parts. The first part of the questionnaire includes data on hotel characteristics where the respondents are employees. The second part includes items that evaluate employer brand dimensions, while the third part of the questionnaire includes items related to competitiveness. The questionnaire contains four general questions and 26 items, 20 evaluate employer brand and 6 items evaluate competitiveness. All items are measured on a 5-point Likert scale, ranging from 1 "I completely disagree" to 5 "I completely agree". 


\subsection{VARIABLES IN THE RESEARCH MODEL}

In order to fulfil the main research objective, it is necessary to define the research model variables. The paper analyses the influence of employer brand, as an independent variable, on hotel's competitiveness, a dependent variable. Employer brand is observed through appropriate dimensions, defined on the results of factor analysis: organizational culture, work-life balance, the attractiveness of the hotel, corporate social responsibility, opportunities for training, development and advancement of employees. The items assessing employer brand development are compiled based on studies by Tanwar and Prasad (2016), Zhu, Wang, Yu, Hu, Wen and Liu (2014), Rampl (2014). Starting from the fact that competitive advantage is defined as a position that a business unit has compared with competitors (Santos, 2000), qualitative assessment of competitiveness is based on the subjective judgment of respondents about the position of the company compared to competitors. The items that assess the dependent variable "competitiveness" in the paper are defined on the studies by Delaney and Huselid (1996); Engstrom, Westnes and Westnes (2003); Aigner and Lloret (2013) as well as Chahal and Bakshi (2015).

\subsection{RESEARCH HYPOTHESES AND STATISTICAL METHODS}

Based on the defined research objective, dependent and independent variables, research involves defining research hypotheses:

Hypothesis 10: There is a positive, significant correlation between employer brand dimensions of the observed hotels.

Hypothesis $\mathbf{1}_{a}$ : There is a negative, significant correlation between employer brand dimensions.

Hypothesis 20: There is a significant impact of employer brand dimensions on competitiveness.

Hypothesis $\mathbf{2}_{a}$ : There is not a significant impact of employer brand dimensions on competitiveness.

Defining employer brand dimensions is done by applying factor analysis. The research hypotheses are tested by applying correlation analysis and multiple regression analysis. Data processing is performed with the support of the Statistical Package for Social Sciences, IBM SPSS Statistics, Version 23. A confidence interval $\alpha=0.05$ is used to determine statistical significance. 


\section{RESEARCH RESULTS AND DISCUSSION}

Descriptive statistics of the observed hotel sample includes the mean value and standard deviation for the observed items on the hotel's employer brand and competitiveness. The best-rated item, when it comes to employer brand, is "Hotel management cares about the environment" (Mean $=4.744)$, while the worst-rated item is "Possibility to improve knowledge" (Mean $=3.656)$. The worst-rated item also has the largest standard deviation $($ St. Dev. $=1.210)$. The mean value of the dependent variable, competitiveness, is 3.809 , while the value of the standard deviation for the same variable is 0.773 .

Factor analysis implies checking the fulfilment of assumptions for its implementation (Pallant, 2011, p.185). The first assumption refers to the sample size in the sense that the number of respondents should be five times larger than the number of items. As employer brand is assessed on the basis of 20 items, the minimum number of respondents should be 100. The sample includes 90 hotels, which means that the sample size is not satisfactory. The second criterion refers to the implementation of two tests, KMO and Barlett's test. The value of the Kaiser-Meyer-Olkin Measure of Sampling Adequacy (KMO) for the observed sample is 0.825 , which is higher than the recommended value of 0.6 (Pallant, 2011, p.185). Barlett's test for the observed sample is statistically significant ( $p$ $=0.000$ ). The results of tests justify the application of the factor analysis. Direct Oblimin Rotation with a given number of factors is used. The characteristic values for all five observed factors are greater than 1, taking into account Kaiser's factor retention criteria. The five factors observed explain $75.28 \%$ of the variance, with the contribution of the first factor being $42.4 \%$, the second factor $10.8 \%$, the third factor $8.4 \%$, the fourth factor $8.1 \%$ and the fifth factor $5.5 \%$.

Direct Oblimin Rotation is used to interpret these five factors. Table 2 provides an overview of the values of factor weights for each observed item, the factor and variable correlation coefficient and part of the variance explained by common factors. In the process of factor analysis, the number of factors (5) is given. Based on the results shown in Table 2, it can be concluded that the items are grouped into the following five employer brand dimensions (factors):

- Organizational culture;

- Work-life balance;

- The attractiveness of the hotel;

- Corporate social responsibility; 
- Opportunities for training, development and advancement of employees.

Table 2

Factor weight matrix and correlation of variables for the employer brand with oblimin rotation of the five-factor solution

\begin{tabular}{|c|c|c|c|c|}
\hline Items & $\begin{array}{l}\text { Factor } \\
\text { weights }\end{array}$ & $\begin{array}{c}\text { Variable } \\
\text { and factor } \\
\text { correlation } \\
\text { coefficient }\end{array}$ & $\begin{array}{c}\text { Part of the } \\
\text { variance } \\
\text { explained by } \\
\text { common } \\
\text { factors }\end{array}$ & Mean \\
\hline Factor 1: Organizational culture & & & & 4.431 \\
\hline Acceptability of organizational culture & 0.888 & 0.913 & 0.841 & \\
\hline Communication with colleagues & 0.828 & 0.796 & 0.640 & \\
\hline Teamwork & 0.786 & 0.864 & 0.777 & \\
\hline $\begin{array}{l}\text { Rotation to other jobs and work in different } \\
\text { roles }\end{array}$ & 0.775 & 0.836 & 0.728 & \\
\hline Factor 2: Work-life balance & & & & 4.508 \\
\hline Hotel paid parental leave & 0.892 & 0.841 & 0.745 & \\
\hline Employee health care & 0.757 & 0.834 & 0.793 & \\
\hline $\begin{array}{l}\text { Leave the workplace in case of a family } \\
\text { emergency }\end{array}$ & 0.740 & 0.783 & 0.644 & \\
\hline Flexible working hours & 0.559 & 0.624 & 0.548 & \\
\hline Factor 3: Attractiveness of the hotel & & & & 4.206 \\
\hline $\begin{array}{l}\text { The hotel is highly reputed nationally and } \\
\text { internationally }\end{array}$ & 0.845 & 0.837 & 0.729 & \\
\hline There are a lot of those who would work in & 0.754 & 0.816 & 0.772 & \\
\hline this hotel & 0.731 & 0.815 & 0.710 & \\
\hline Hotel is a great place to work & 0.405 & 0.617 & 0.682 & \\
\hline I am proud to work in this hotel & & & & \\
\hline Factor 4: Corporate social responsibility & & & & 4.624 \\
\hline $\begin{array}{l}\text { Environmental protection } \\
\text { Caring for the local community }\end{array}$ & 0.909 & 0.922 & 0.867 & \\
\hline Resolving complaints in a short time & 0.795 & 0.844 & 0.724 & \\
\hline Freedom to report undesirable behaviour & 0.705 & 0.839 & 0.792 & \\
\hline & 0.387 & 0.627 & 0.764 & \\
\hline $\begin{array}{l}\text { Factor 5: Opportunities for training, } \\
\text { development and advancement of } \\
\text { employees }\end{array}$ & & & & 3.871 \\
\hline Possibility to improve knowledge & 0.902 & 0.930 & 0.879 & \\
\hline Availability of training programs & 0.894 & 0.920 & 0.853 & \\
\hline Possibility of advancement & 0.874 & 0.874 & 0.777 & \\
\hline $\begin{array}{l}\text { Availability of information on open } \\
\text { positions }\end{array}$ & 0.783 & 0.874 & 0.794 & \\
\hline
\end{tabular}

Note. Authors' calculations.

The interpretation of the obtained factors is in accordance with previous research (Zhu et al., 2014; Tanwar \& Prasad, 2016). The results obtained 
indicate that all five employer brand factors (dimensions) have high values of factor weights. Among the observed five factors, there is mainly a negative, weak and medium correlation, with the strongest correlation identified between factor 1: Organizational culture and factor 5: Opportunities for training, development and advancement of employees $(r=-0.488)$.

Based on mean values (Table 2), the best-rated dimensions by hotel employees are: Corporate social responsibility, Work-life balance, Organizational culture, Attractiveness of the hotel, Opportunities for training, development and advancement of employees.

The reliability and consistency of the applied items is measured based on Cronbach's alpha coefficient. This coefficient for the whole model is 0.822 , which is more than the minimum recommended value of 0.700 (Nunnally, 1978). For other variables, Cronbach's alpha coefficient ranges from 0.768 to 0.820 (see Table 3). Based on the results obtained, it can be concluded that the reliability and consistency of the observed items, and, thus, the variables, are high.

\section{Table 3}

Results of the reliability analysis

\begin{tabular}{lc}
\hline Variables & Cronbach's alpha coefficient \\
\hline Organizational culture & 0.783 \\
Work-life balance & 0.820 \\
Attractiveness of the hotel & 0.794 \\
Corporate social responsibility & 0.768 \\
Opportunities for training, development & 0.788 \\
and advancement of employees & 0.804 \\
Competitiveness & \\
\hline
\end{tabular}

Note. Authors' calculations.

The research Hypothesis 1 is tested by applying correlation analysis. This analysis tests the strength and direction of the correlation between the observed variables, in this case among employer brand dimensions. 
Table 4

Correlation matrix

\begin{tabular}{lrrrrrr}
\hline Variables & \multicolumn{1}{l}{ OC } & W-LB & AH & CSR & TDA & C \\
\hline OC & 1 & & & & & \\
W-LB & $0.325^{* *}$ & 1 & & & & \\
AH & $0.419^{* *}$ & $0.346^{* *}$ & 1 & & & \\
CSR & $0.629^{* *}$ & $0.412^{* *}$ & $0.519^{* *}$ & 1 & & \\
TDA & $0.538^{* *}$ & $0.383^{* *}$ & $0.503^{* *}$ & $0.535^{* *}$ & 1 & \\
C & $0.445^{* *}$ & $0.267^{*}$ & $0.393^{* *}$ & $0.532^{* *}$ & $0.413^{* *}$ & 1 \\
\hline
\end{tabular}

Note. Authors' calculations.

$O C$ - Organizational culture; W-LB - Work-life balance; AH - Attractiveness of the hotel; CSR - Corporate social responsibility; TDA - Training, development, the advancement of employees; $C$ - Competitiveness

Significance: $* * \mathrm{p} \leq 0.01 ; * \mathrm{p} \leq 0.05$

Based on the results of the correlation analysis presented in Table 4, it can be concluded that Hypothesis $\mathbf{1}_{\mathbf{0}}$ is supported while the alternative Hypothesis $1_{\mathrm{a}}$ is not supported, so it can be concluded that there is a positive, significant correlation between employer brand dimensions. Correlation is the strongest between Organizational culture and Corporate social responsibility $(\mathrm{r}=0.629$; $\mathrm{p}=0.000$ ), while the weakest correlation is identified between Organizational culture and Work-life balance $(\mathrm{r}=0.325 ; \mathrm{p}=0.002)$. Competitiveness is most strongly correlated with Corporate social responsibility $(\mathrm{r}=0.532 ; \mathrm{p}=0.000)$.

Table 5

Results of regression analysis

\begin{tabular}{lr|r|r}
\hline Independent variables & \multicolumn{3}{|c}{ Standard multiple regression } \\
\cline { 2 - 4 } & \multicolumn{1}{c|}{ Beta } & $\mathrm{t}$ value & \multicolumn{1}{c}{ Sig. } \\
Organizational culture & 0.129 & 1.052 & 0.296 \\
Work-life balance & 0.009 & 0.086 & 0.932 \\
Attractiveness of the hotel & 0.108 & 0.963 & 0.338 \\
$\begin{array}{l}\text { Corporate social responsibility } \\
\begin{array}{l}\text { Opportunities for training, } \\
\text { development and advancement of }\end{array}\end{array}$ & $\mathbf{0 . 3 3 4}$ & $\mathbf{2 . 5 6 9}$ & $\mathbf{0 . 0 1 2 *}$ \\
employees & 0.107 & 0.899 & 0.371 \\
\hline
\end{tabular}

Note. Authors' calculations.

Dependent variable: Competitiveness; Significance: $* * \mathrm{p} \leq 0.01 ; * \mathrm{p} \leq 0.05 ; R^{2}=0.324$; $F=7.876 ; p=0.000$

Testing the impact of a hotel's employer brand dimensions on competitiveness is performed by applying multiple regression analysis. Regression analysis SCHOOL OF BUSINESS, 2/2020, 35-61 
involves checking the fulfilment of assumptions: multicollinearity and autocorrelation (Pallant, 2011). Multicollinearity is monitored based on the VIF coefficient, which should not exceed 5. Autocorrelation is monitored based on the value of Durbin-Watson statistics, which should not exceed 4. In this case, the VIF coefficient for the observed independent variables does not exceed 5, while the value of Durbin-Watson statistics is 2.179.

The coefficient of determination in the observed model is $\mathrm{R}^{2}=0.324$, which means that $32 \%$ of the competitiveness variance is explained by the regression model, while the rest is influenced by other factors. The value of Adjusted $\mathrm{R}$ Square is 0.283 , while the value of $F$ statistics is 7.876. Values of $\beta, t$ and Sig. are given in Table 5 .

Based on the results of multiple regression analysis, it can be concluded that Hypothesis $2_{0}$ is supported. In contrast, the alternative Hypothesis $2_{a}$ is not supported, so it can be concluded that there is a significant impact of a hotel's employer brand dimensions on competitiveness. Corporate social responsibility has a significant impact on competitiveness $(\beta=0.334 ; \mathrm{t}=2.569 ; \mathrm{p}=0.012)$, which is to be expected, since these two variables are most strongly correlated.

Corporate social responsibility plays a key role in achieving a competitive advantage (Velazquez-Cazares et al., 2021). Authors Tanwar and Prasad (2016) conclude that different corporate social responsibility programs can be linked to the company's core values and strategic missions to ensure maximum effort of employees. The relationship between corporate social responsibility and competitiveness has been supported by: Madue et al. (2016); Hoppe (2018); Guo \& Lu (2021) and Hadj (2020). Social responsibility programs are implemented by employees. Therefore, employees must understand and believe in defined social responsibility programs to present them in the right way to other stakeholders. Hotel management must first start by creating social responsibility towards employees, who will continue to promote social responsibility programs towards other stakeholders.

\section{CONCLUSION}

Creating a strong competitive hotel position on the market relies increasingly on the use of internal resources, primarily human. Efficient use of these resources implies the development of appropriate strategies aiming to strengthen the value of human capital by attracting and retaining talented employees. Research shows that it is useful to implement an employer branding strategy for these purposes. 
The results of factor analysis, with the application of direct Oblimin Rotation, clearly indicate five employer brand factors or dimensions for the observed sample: organizational culture, work-life balance, the attractiveness of the hotel, corporate social responsibility, opportunities for training, development and advancement of employees. Thus defined, employer brand dimensions are in line with the previous research findings (Zhu et al., 2014; Tanwar \& Prasad, 2016), used to define items in the questionnaire. The results of the correlation analysis support Hypothesis $1_{0}$. Correlation is the strongest between Organizational culture and Corporate social responsibility $(\mathrm{r}=0.629 ; \mathrm{p}=$ 0.000), while competitiveness is most strongly correlated with Corporate social responsibility $(\mathrm{r}=0.532 ; \mathrm{p}=0.000)$. The regression analysis results indicate a significant impact of a hotel's employer brand dimensions on competitiveness and Hypothesis $2_{0}$ is supported. Among employer brand dimensions, Corporate social responsibility has significant impact on competitiveness $(\beta=0.334 ; \mathrm{t}=$ $2.569 ; \mathrm{p}=0.012$ ).

This study has several theoretical implications. First, previous research examined the importance of the employer brand for attracting potential employees (Tanwar \& Prasad, 2016). The focus of this study is on current employees and the employer brand dimensions that they particularly value. Second, a certain number of researchers have used the EmpAt scale to analyze the employer brand (Alniacik \& Alniacik, 2012; Alniacik, Alniacik, Erat \& Akcin, 2014; Ahmad \& Daud, 2015; Reis \& Braga, 2016) and instrumentalsymbolic framework (Lievens \& Highhouse, 2003; Van HoyeBas, Cromheecke \& Lievens, 2013; Xie, Bagozzi \& Meland, 2015). As these frameworks are not the best solution for the employer brand analysis among current employees, this study identifies slightly different employer dimensions than those offered by these frameworks. Third, some research on the employer brand has been conducted in Western countries (Sharma \& Prasad, 2018) and India (Tanwar \& Prasad, 2016; Sharma \& Prasad, 2018; Maurya \& Agarwal, 2018; Kashyap \& Verma, 2018; Deepa \& Baral, 2019; Chawla, 2020). This study provides a theoretical contribution by researching employer brand development by focusing on Serbia. Fourth, a large number of studies have analyzed the importance and role of the employer brand in companies of different industries (Kashive, Khanna \& Bharthi, 2020) in the IT industry (Tanwar \& Prasad, 2016; Kashyap \& Verma, 2018; Deepa \& Baral, 2019); service industries (Schlager, Bodderas, Maas \& Cachelin, 2011; Arasanmi \& Krishna, 2019; Chawla, 2020). The study focuses on the hotel industry and analyzes the relationship between the employer brand and competitiveness.

This study builds on previous studies on the importance of the employer brand for employees (Kucherov \& Zavyalova, 2012; Tanwar \& Prasad, 2016; Kashyap \& Verma, 2018; Deepa \& Baral, 2019; Chawla 2020). Most SCHOOL OF BUSINESS, 2/2020, 35-61 
companies take care of their employees and their satisfaction and engagement, but they do not deal specifically with the employer brand dimensions that are the most important for employees (Davies, Mete \& Whelan, 2018). By carefully considering the employer brand dimensions, which managers assess as the most important, they can be changed and improved over time for the more efficient operation of human resources. The best-rated dimensions by hotel employees are corporate social responsibility, work-life balance, organizational culture, the attractiveness of the hotel, opportunities for training, development and advancement of employees. By strengthening these dimensions and investing in them, it is possible to achieve the ultimate goal of the employer branding strategy: motivation increase and employee satisfaction.

This study aimed to identify the dimensions that improve the hotel's competitiveness, which had been analyzed only indirectly in previous studies. The research results coincide with the conclusion of the authors Kucherov and Zavyalova (2012) that companies with employer brand invest more in employees' knowledge and competencies to make them more qualified and loyal, which affect the competitive advantage of the company. The study provides important managerial implications because it identifies the employer brand dimensions that strengthen competitiveness. This primarily refers to Corporate social responsibility, a dimension that significantly affects competitiveness. The research results also indicate a positive, significant relationship between the observed dimensions of the employer brand. Such results should be kept in mind when developing and investing in the employer brand dimensions since the growth of one dimension affects the growth of another and vice versa. By developing and linking the observed employer brand dimensions, it is possible to increase the employer brand assets' value.

The research has several limitations. The first limitation refers to the sample size in terms of meeting the assumptions for factor analysis. The number of respondents should be five times higher than the number of items, which in this case would be 100 , and the sample size is 90 . However, other preconditions for factor analysis have been met (KMO and Barlett's test), which justified further factor analysis. Another limitation relates to the way hotel's employer brand dimensions and competitiveness are assessed. It is recommended to use appropriate mathematical methods to express the value of employer brand and especially competitiveness quantitatively. An alternative to this model is a qualitative assessment of their value, which comes down to the subjective assessment of managers surveyed. The third research limitation builds on the second because the respondents assess the current situation with the hotel's 
employer brand and competitiveness, without insight into their trend in previous years and possible forecasts.

\section{REFERENCES}

Ahmad, S., \& Schroeder, R. (2011). Knowledge management through technology strategy: implications for competitiveness. Journal of Manufacturing Technology Management, 22(1), 6-24.

Aigner, D., \& Lloret, A. (2013). Sustainability and competitiveness in Mexico. Management Research Review, 36(12), 1252 - 1271.

Alniacik, E., \& Alniacik, U. (2012). Identifying dimensions of attractiveness in employer branding: effects of age, gender, and current employment status. Procedia - Social and Behavioral Sciences, 58, 1336 1343.

Alniacik, E., Alniacik, U., Erat, S., \& Akcin, K. (2014). Attracting Talented Employees to the Company: Do We Need Different Employer Branding Strategies in Different Cultures? Procedia - Social and Behavioral Sciences, 150, $336-344$.

Alpander, G., \& Lee, C. (1995). Culture, strategy and teamwork The keys to organizational change. Journal of Management Development, 14(8), 4-18.

Alshathry, S., Clarke, M, \& Goodman, S. (2017). The role of employer brand equity in employee attraction and retention: a unified framework. International Journal of Organizational Analysis, 25(3), 413-431.

Ambler, T., \& Barrow, S. (1996). The employer brand. The Journal of Brand Management, 4(3), 185-205.

Anderson, E. (1990). Two firms, one frontier: on assessing joint venture performance. Sloan Management Review, 31(2), 19-30.

Anning-Dorson, T. (2021).Organizational culture and leadership as antecedents to organizational flexibility: implications for SME competitiveness. Journal of Entrepreneurship in Emerging Economies.

Arasanmi, C., \& Krishna, A. (2019). Employer branding: perceived organisational support and employee retention - the mediating role of organisational commitment. Industrial and Commercial Training, 51(3), 174183.

Backhaus K., \& Tikoo, S. (2004). Conceptualizing and researching employer branding. Career Development International, 9(5), 501 - 517. 
Batarlien, N., Čižiūniene, K., Vaičiūte, K., Šapalaite, I., \& Jarašūniene, A. (2017). The Impact of Human Resource Management on the Competitiveness of Transport Companies. Procedia Engineering, 187(2017), $110-116$.

Baumann, C., Hamin, H., Tung, R., \& Hoadley, S. (2016). Competitiveness and workforce performance: Asia vis-à-vis the "West". International Journal of Contemporary Hospitality Management, 28(10), 2197 $-2217$.

Boulouta, I., \& Pitelis, C.N. (2014). Who needs CSR? The impact of corporate social responsibility on national competitiveness. Journal of Business Ethics, 119(3), 349-364.

Campos-Soria, J.A., García, L.G., \& García, M.A.R. (2005). Service quality and competitiveness in the hospitality sector, Tourism Economics, 11(1), 85-102.

Cetindamar, D., \& Kilitcioglu, H. (2013). Measuring the competitiveness of a firm for an award system. Competitiveness Review: An International Business Journal, 23(1), 7-22.

Chahal, H., \& Bakshi, P. (2015). Examining intellectual capital and competitive advantage relationship Role of innovation and organizational learning. International Journal of Bank Marketing, 33(3), 376 - 399.

Chawla, P. (2020). Impact of employer branding on employee engagement in business process outsourcing (BPO) sector in India: mediating effect of person-organization fit. Industrial and Commercial Training, 52(1), $35-49$.

Cheung, H.Y., \& Chan, A. (2012). Increasing the competitive positions of countries through employee training The competitiveness motive across 33 countries. International Journal of Manpower, 33(2), 144-158.

CIPD (2007). Employer Branding: The Latest Fad or Future of HR? London: Chartered Institute of Personnel and Development.

Davies, G., Mete, M., \& Whelan, S. (2018). When employer brand image aids employee satisfaction and engagement. Journal of Organizational Effectiveness: People and Performance, 5(1), 64-80.

Deepa, R., \& Baral, R. (2019). Importance-performance analysis as a tool to guide employer branding strategies in the IT-BPM industry. Journal of Organizational Effectiveness: People and Performance, 6(1), 77-95. 
Delaney, J.T., \& Huselid, M.A. (1996). The impact of human resource management practices on perceptions of organizational performance. Academy of Management Journal, 39, 949-969.

Dragicevic,M., Cizmar, S., \& Seric, M. (1999). Competitiveness of Croatian hotel sector. Revue de Tourisme - The Tourist Review - Zeitschrift für Fremdenverkehr, 2(1999), 30-40.

Drezner, T., Drezner, Z., \& Zerom, D. (2018). Competitive facility location with random attractiveness. Operations Research Letters, 46(2018), 312-317.

Engstrom, T., Westnes, P., \& Westnes, S. F. (2003). Evaluating intellectual capital in the hotel industry. Journal of Intellectual Capital, 4(3), $287-303$.

Gómez-Miranda, E., Pérez-López, C., Argente-Linares, E., \& RodríguezAriza, L. (2015). The impact of organizational culture on competitiveness, effectiveness and efficiency in Spanish-Moroccan international joint ventures. Personnel Review, 44(3), 364 - 387.

Gómez-Miranda, E., Pérez-López, C., Argente-Linares, E., \& RodríguezAriza, L. (2015).The impact of organizational culture on competitiveness, effectiveness and efficiency in Spanish-Moroccan international joint ventures. Personnel Review, 44(3), 364-387.

Guo, H., \& Lu, W. (2021). The inverse U-shaped relationship between corporate social responsibility and competitiveness: evidence from Chinese international construction companies. Journal of Cleaner Production.

Hadj, T.B. (2020). Effects of corporate social responsibility towards stakeholders and environmental management on responsible innovation and competitiveness. Journal of Cleaner Production, 250(2020), 119490.

Holjevac, I. A. (2011). Work productivity in the Croatian hotel industry fundamentals and concepts for achieving growth and competitiveness. South East European Journal of Economics and Business, 5(5), 85-90.

Hoppe, D. (2018). Linking employer branding and internal branding: establishing perceived employer brand image as an antecedent of favourable employee brand attitudes and behaviours. Journal of Product \& Brand Management, 27(4,) 452-467.

Husain, Z., Dayan, M., \& Benedetto, A.D. (2016). The impact of networking on competitiveness via organizational learning, employee innovativeness, and innovation process: A mediation model. Journal of Engineering and Technology Management, 40(2016), 15-28. 
58 | RESEARCH ON IMPACT OF EMPLOYER BRAND DIMENSIONS ON COMPETITIVENESS IN HOTEL INDUSTRY

Ioncica, M., Tala, M., Brindusoiu, C., \& Ioncica, D. (2008). The factors of competitiveness in the hospitality industry and the competitive strategy of firms. Annals of the University of Oradea, Economic Science Series, 17(2), 213218.

Kashive, N., Khanna, V.T., \& Bharthi, M.N. (2020). Employer branding through crowdsourcing: understanding the sentiments of employees. Journal of Indian Business Research, In press.

Kashyap, V., \& Verma, N. (2018). Linking dimensions of employer branding and turnover intentions. International Journal of Organizational Analysis, 26(2), 282-295.

Kaya, B., \& Karatepe, O. (2020). Attitudinal and behavioral outcomes of work-life balance among hotel employees: The mediating role of psychological contract breach. Journal of Hospitality and Tourism Management, 42(2020), 199-209.

Kim, C. (2000). A Model Development for Measuring Global Competitiveness of the Tourism Industry in the Asia-Pacific Region, Seoul: Korea Institute for International Economic Policy.

Kucherov, D., \& Zavyalova, E. (2012). HRD practices and talent management in the companies with the employer brand. European Journal of Training and Development, 36, 86-104.

Le, H., Newman, A., Menzies, J., Zheng, C., \& Fermelis, J. (2020). Work-life balance in Asia: A systematic review. Human Resource Management Review, 30(2020).

Lievens, F., \& Highhouse, S. (2003). The relation of instrumental and symbolic attributes to a companys attractiveness as an employer. Personnel psychology, 56, 75-102.

Madue, J.H., Jorge, M.L., Conesa, I.M., \& Martínez-Martínez, D. (2016). Relationship between corporate social responsibility and competitive performance in Spanish SMEs: Empirical evidence from a stakeholders' perspective. Business Research Quarterly, 19(2016), 55-72.

Maurya, K. K., \& Agarwal, M. (2018). Organisational talent management and perceived employer branding. International Journal of Organizational Analysis, 26(2), 312-330.

Maxwell, R., \& Knox, S. (2009). Motivating employees to 'live the brand': a comparative case study of employer brand attractiveness within the firm. Journal of Marketing Management, 25(9/10), 893-907. 
Navickas, V., \& Malakauskaite, A. (2009). The possibilities for the identification and evaluation of tourism sector competitiveness factors. The Economic Conditions of Enterprise Functioning, 1(6), 37-44.

Nunes, S., Estevão, C., \& Filipe, M.N. (2018). Determinant factors of competitiveness in the hotel sector: the case of Portugal. Competitiveness Review: An International Business Journal, 28(2), 122-135.

Nunnally, J.C. (1978). Introduction to Psychological Measurement. New York: McGraw-Hill.

Ognjanović, J. (2020). Employer brand and workforce performance in hotel companies. Hotel and Tourism Management, 8(2), 65-78.

Ognjanović, J., \& Slavković, M. (2019). Impact of employer brand on employees satisfaction in Serbian hotel enterprises, in: Cvijanović, D. et al. (Eds.): Tourism in function of development of the Republic of Serbia - Tourism as a generator of Employment, Vrnjačka Banja: University of Kragujevac, Faculty of Hotel Management and Tourism in Vrnjačka Banja, 254-271. knjiga.

Pallant, J. (2011). SPSS priručnik za preživljavanje. Beograd: Mikro

Pereira-Moliner, J., Pertusa-Ortega, E., Tarí, J.J., López-Gamero, M., \& Molina-Azorín, J. (2016). Organizational design, quality management and competitive advantage in hotels. International Journal of Contemporary Hospitality Management, 28(4), 762 - 784.

Phillips, P. (1999). Hotel performance and competitive advantage: a contingency approach. International Journal of Contemporary Hospitality Management, 11(7), $359-365$.

Rai, A. (2020). An application of the instrumental-symbolic framework in Maritime industry A study on employer branding among seafarers. Management Research Review, 43(3), 270-292.

Rampl, L.V. (2014). How to become an employer of choice: transforming employer brand associations into employer first-choice brands. Journal of Marketing Management, 30(13/14), 1486-1504.

Reis, G.G., \& Braga, B.M. (2016). Employer attractiveness from a generational perspective: Implications for employer branding. R.Adm., São Paulo, 51(1), 103-116.

Rodríguez-Victoria, O.E., Puig, F., \& González-Loureiro, M. (2017). Clustering, innovation and hotel competitiveness: evidence from the Colombia destination. International Journal of Contemporary Hospitality Management, 29(11), 2785-2806.

SCHOOL OF BUSINESS, 2/2020, 35-61 
60 | RESEARCH ON IMPACT OF EMPLOYER BRAND DIMENSIONS ON COMPETITIVENESS IN HOTEL INDUSTRY

Sanchez-Gutierrez, J., Mejia-Trejo, J., Vargas-Barraza, J.A., \& VazquezAvila, G. (2016). Intellectual capital, impact factor on competitiveness: manufacturing industry SMEs in Mexico. Measuring Business Excellence, $20(1), 1-11$.

Santiago, J. (2019). The relationship between brand attractiveness and the intent to apply for a job A millennials' perspective. European Journal of Management and Business Economics, 28(2), 142-157.

Santos, F. (2000). Integration of human resource management and competitive priorities of manufacturing strategy. International Journal of Operations \& Production Management, 20(5), 610 - 628.

Schlager, T., Bodderas, M., Maas, P., \& Cachelin, J.L. (2011). The influence of the employer brand on employee attitudes relevant for service branding: an empirical investigation. Journal of Services Marketing, 25(7), 497 -508 .

Sharma, R., \& Prasad, A. (2018). Employer brand and its unexplored impact on intent to join. International Journal of Organizational Analysis, 26(3), 536-566.

Sigalas, C., Economou, V.P., \& Georgopoulos, N. (2013). Developing a measure of competitive advantage. Journal of Strategy and Management, 6(4), 320-342.

Slavković, M., \& Ognjanović, J. (2017). The influence of human capital on the copmetitiveness of hotels in Serbia. In: Štetić, S. et al. (Eds.), Modern management tools and economy of tourism sector in present era: Second internationall thematic monograph (115-128). Beograd: Association of Economists and Managers of the Balkans in cooperation with Faculty of Tourism and Hospitality, Ohrid, Macedonia.

Tanwar, K., \& Prasad, A. (2016). The effect of employer brand dimensions on job satisfaction: gender as a moderator. Management Decision, $54(4), 854-886$.

Tuclea, C.E., \& Padurean, A.M. (2008). Competitiveness in hospitality industry: Romanian style. Journal Management \& Marketing, 6(1), 105-114.

Van Hoye, G., Bas, T., Cromheecke, S., \& Lievens, F. (2013). The instrumental and symbolic dimensions of organizations' image as an employer: A large-scale field study on employer branding in Turkey. Applied Psychology: An International Review, 62, 543-557. 
Velazquez-Cazares, M., Leon-Castro, E., Blanco-Mesa, F., \& AlvaradoAltamirano, S. (2021).The ordered weighted average corporate social responsibility. Kybernetes.

Vij, M. (2016). The cost competitiveness, competitiveness and sustainability of the hospitality industry in India. Worldwide Hospitality and Tourism Themes, 8(4), 432-443.

Wang, F., Huang, W., \& Shang, J. (2006). Measuring the cost-efficiency of international tourist hotels in Taiwan. Tourism Economics, 12(1), 65-85.

Wong, K., \& Kwan, C. (2001). An analysis of the competitive strategies of hotels and travel agents in Hong Kong and Singapore. International Journal of Contemporary Hospitality Management, 13(6), 293 - 303.

Xiaa, H., Vuc, H.Q., Lawd, R., \& Li, G. (2020). Evaluation of hotel brand competitiveness based on hotel features ratings. International Journal of Hospitality Management, 86(2020).

Xie, C., Bagozzi, R., \& Meland, K. (2015). The impact of reputation and identity congruence on employer brand attractiveness. Marketing Intelligence \& Planning, 33(2), $124-146$.

Zhu, F., Wang, Z., Yu, Q., Hu, T., Wen, Y., \& Liu, Y. (2014). Reconsidering the dimensionality and measurement of employer brand in the chinese context. Social behavior and personality, 42(6), 933-948.

Delivered: 20.10.2020.

Accepted: 10.02.2021. 